\title{
Study on the Wound Healing Activity of TANUVAS Nano-Heal Topical Gel in Clinical Cases of Cattle and Turkey
}

\author{
N. V. Rajesh ${ }^{1}$, S. Ilavarasan ${ }^{2}$ and T. A. Vijayalingam ${ }^{1 *}$ \\ ${ }^{1}$ Veterinary University Training and Research Centre, Ramanathapuram, Tamilnadu \\ Veterinary and Animal Sciences University, Chennai, India \\ ${ }^{2}$ Regional Research and Educational Centre, Pudukottai, Tamilnadu Veterinary and Animal \\ Sciences University, Chennai, India \\ *Corresponding author
}

\section{A B S T R A C T}

Keywords

TANUVAS Nano-

Heal Topical gel,

Wound healing activity, Bacterial load, Epithelisation time

\section{Article Info}

Accepted:

17 June 2020

Available Online:

10 July 2020
A study to ascertain the efficacy of TANUVAS Nano-Heal Cream in wound healing in animals was conducted. The work was carried out in Veterinary Dispensaries of Uchipuli and Rameswaram, a dairy farm at pattinamkathan town, a turkey farm at Mothivalasi village and a dairy unit at Alagankulam of Ramanathapuram district. A total of 25 clinical cases of wound in animals (24 Cattles and 1 Turkey) were taken for the study. The cases included FMD myiasis $(n=6)$, Surgical wound $(n=4)$, Foot rot condition $(n=4)$, Ruptured pox lesions $(n=4)$, Udder abscess $(n=1)$ and Lacerated wounds $(n=6)$. The gross physical appearance and dimension of the wound were recorded before treatment. The status of healing was recorded for a period of 15 days. The areas of the wounds were measured in $\mathrm{mm}$ in every 3 days interval of post treatment with the aid of vernier caliper. The number of application of TANUVAS Nano-Heal cream per clinical case and the time taken for the formation of granulation tissue were recorded. The efficacy of the gel is ascertained by counting the bacterial load both before treatment $\left(0^{\text {th }}\right.$ Day) and during healing period $\left(5^{\text {th }}\right.$ Day). It was proved that TANUVAS Nano-Heal topical gel formulation has got potential wound healing activity and the efficacy of the Nano-heal gel depended on nature and type of wound and was better in reducing the microbial load significantly after continuous application for a minimum period of (6 Days) in surgical wounds and a maximum period of (12 Days) in FMD hoof wounds and udder abscess wound. The irregular old wounds took longer time compared to the fresh surgical wound.

\section{Introduction}

Wounds and healing are two important factors in animals and human life. Wound is defined as the disruption of cellular and anatomic continuity of a tissue (Bennet, 1988) which are produced by multiple factors like physical, chemical, thermal, microbial or immunological insult (Rajinder et al., 2008). Wound healing is a complex process of interrelated events mediated through a wide range of chemically coordinated cellular processes as well as hormonal influences (Chan et al., 2008). The methods in current 
trends to treat wounds include debridement, irrigation, antibiotics, tissue grafts, proteolytic enzymes and corticosteroids which possess major drawbacks and unwanted side effects (Nayak et al., 2010). The aim of treating a wound is to promote wound healing in a shorter period without much pain and discomfort to the animals.

Nowadays antibacterial and antiseptic drug resistance is a problem in the field condition resulting in poor drug response. Wound in livestock is a major commonly prevailing problem and are ubiquitous in nature. The delayed wound healing process due to repetitive use of antibiotics is of major concern in livestock. In certain wounds the power of penetration of medicines may be hindered by debris, antibiotic resistance etc. To overcome such difficulties, nano formulation of medicine would be of much valuable. Nano formulation for wound healing in animal is a unique combination of natural polymers mainly used for their medical applications due to their biocompatibility, high suitability for ligand mobilization, cross linking and other functional modifications (Boateng et al., 2008 and Mogosanu and Grumezescu, 2014). The natural polymers are non-toxic and biocompatible ingredients that accelerate wound healing and exert anti-bacterial effects (Viswanathan et al., 2016). Nano-Heal formulation consists of gelatin and chitosan as the natural polymer followed by addition of $2 \%$ chlorhexidine and 5\% calcium phosphate nanoparticle (Viswanathan et al., 2016). The gelatin exhibited good film forming capacity and it also helps to prevent the fluid loss from the injured sites and also act as a biological substrate to culture adherent cells (Chen et al., 2003 and Tanaka et al., 2005). The chitosan molecules also exhibited minimal foreign body reaction and have easy functional group attachments to other molecules (Azad et al., 2004 and Ong et al., 2008). Addition of
Chlorhexidine which are active against gram positive, gram negative, anaerobes, aerobes and yeasts is an added advantage in wound healing. Chlorohexidine also inhibits the biofilm formations (Mullany et al., 2006). The calcium phosphate nanoparticles used in this product easily disintegrate in acidic $\mathrm{pH}$, thereby releasing calcium ions on the wound surface. It can act as a vehicle for delivering growth factors and drugs in tissue engineering (Bose and Tarafder, 2012). Apart from all, this is the first cream contained both natural polymers, nanoparticles with chlorhexidine produced in veterinary field. This study is proposed to assess the efficacy of TANUVAS Nano-Heal cream towards wound healing activity in animals under field conditions.

\section{Materials and Methods}

The study on the wound healing ability of TANUVAS Nano-Heal Cream in animals of Ramanathapuram was conducted during June to November 2019. Wound cases attending Out Patient units of Veterinary Dispensaries of Uchipuli and Rameswaram, a hoof wound case in a cow at pattinamkathan town (Fig 1 and 2) and a chronic udder abscess in a cow at Alagankulam village (Fig 3 and 4) and a neck lacerated wound in a turkey at Mothivalasi village (Fig 5 and 6) were the prominent cases served the purpose of this study. A total of 25 clinical wound cases in animals (24 Cattles and 1 Turkey) were taken for the study which included FMD myiasis ( $n=6)$, Surgical wound $(n=4)$, Foot rot condition $(n=4)$, Ruptured pox lesions $(\mathrm{n}=4)$, Udder abscess $(\mathrm{n}=1)$ and Lacerated wounds $(n=6)$. The gross physical appearance of the wound and the status of healing were recorded for a period of 15 days. The areas of the wounds were measured in $\mathrm{mm}$ in every 3 days interval of post treatment with the aid of vernier caliper. The number of application of TANUVAS Nano-Heal cream per clinical case and the time taken for the formation of granulation tissue were taken. 
The efficacy of the gel is ascertained by counting the bacterial load both before treatment $\left(0^{\text {th }}\right.$ Day $)$ and during healing period $\left(5^{\text {th }}\right.$ Day). The application of TANUVAS nano-heal cream was carried out only after following strict aseptic cleaning procedures.

\section{Maggot wounds}

The maggot infested lacerated wounds and the wounds resulted due to FMD were treated with this Nano cream very effectively by got rid of the maggots from the wound with turpentine oil and forceps. The debridement of wound was done with forceps and scissors. Normal saline and $1 \%$ Potassium permanganate solution were used to clean the wounds. The cleaned and dried wounds were applied with TANUVAS Nano-Heal cream. The farmer was advised to repeat the treatment twice a day until complete recovery.

\section{Surgical wounds}

The wound area was applied with TANUVAS Nano-Heal cream after cleaning with Povidone Iodine. The owner/farmer was also advised to repeat the treatment twice a day until complete healing.

\section{Foot rot}

The wound in the hoof region was cleaned with turmeric mixed lukewarm water to remove the dirt and debris. Then the hoof was cleaned with potassium permanganate solution before the application of TANUVAS Nano-Heal cream. The farmer was advised to repeat the treatment twice a day until complete healing.

\section{Pox lesions in teats}

The wound formed due to the rupture of pox vesicles on teat were initially cleaned with Boric acid solution and wiped out to dry the wound and was applied with TANUVAS Nano-Heal cream. Advised to repeat the treatment twice a day till the healing completed.

\section{Udder abscess}

An udder abscess in a non-descriptive milch animal was treated successfully with TANUVAS Nano-Heal cream. The unhealed mouth of the incised, drained and treated abscess was cleaned with saline and $1 \%$ potassium permanganate solution. Then TANUVAS Nano Heal cream was applied twice a day.

\section{Results and Discussion}

Wound healing is a regenerative process in which injured/damaged tissues are repaired by various stages of healing process to bring down the normal morphological features. The physiological parameters of wound healing activity like time taken for complete healing of different types of wounds, number of topical application of TANUVAS Nano-Heal gel required for complete healing and the bacterial load of the wound before and after the application of Nano-Heal gel are presented in (Table 1). The healing pattern of the different types of wound is given in (Table 2). A total of 25 clinical cases of wound were considered for this study. A FMD hoof wound in a cow infested with maggots (Fig 1 and 2) and unhealed mouth of an udder abscess in a non-descript animal (Fig 3 and 4) had taken more days for healing (12 Days). The healing time was comparatively lesser in case of surgical sterile wounds $(6$ days). Although the numbers of bacterial colonies were found to be reduced in FMD myiasis on the $5^{\text {th }}$ day of treatment, the effectiveness of healing process was found to be low when compared to the other types of wounds encountered during this study. 
Table.1 Physiological parameters and Bacterial load count of different types of wound

\begin{tabular}{|c|c|c|c|c|c|c|c|}
\hline \multirow{2}{*}{$\begin{array}{l}\text { S. } \\
\text { No }\end{array}$} & \multirow[t]{2}{*}{ Type of wound } & \multirow{2}{*}{$\begin{array}{l}\text { Species } \\
\text { affected }\end{array}$} & \multirow{2}{*}{$\begin{array}{l}\text { No. of } \\
\text { cases }\end{array}$} & \multirow{2}{*}{$\begin{array}{l}\text { No of } \\
\text { application } \\
\text { / case }\end{array}$} & \multirow{2}{*}{$\begin{array}{l}\text { Time for complete } \\
\text { healing/ case } \\
\text { (Days) }\end{array}$} & \multicolumn{2}{|c|}{ Bacterial count $\left(\mathbf{c f u} / \mathrm{cm}^{2}\right)$} \\
\hline & & & & & & $\begin{array}{c}\text { Before } \\
\text { treatment }\end{array}$ & $\begin{array}{c}\text { After } \\
\text { treatment }\end{array}$ \\
\hline 1. & FMD myiasis & Cattle & 6 & 24 & 12 & $7.8 \times 10^{7}$ & $1.7 \times 10^{7}$ \\
\hline 2. & Surgical wound & Cattle & 2 & 12 & 6 & $1.2 \times 10^{3}$ & 0 \\
\hline 3. & Foot rot & Cattle & 4 & 18 & 9 & $3.0 \times 10^{8}$ & $1.2 \times 10^{7}$ \\
\hline 4. & Ruptured Pox lesions & Cattle & 4 & 18 & 9 & $5.0 \times 10^{5}$ & $1.4 \times 10^{5}$ \\
\hline 5. & $\begin{array}{l}\text { Unhealed mouth of a } \\
\text { completely evacuated and } \\
\text { drained udder abscess }\end{array}$ & Cattle & 1 & 24 & 12 & $3.8 \times 10^{7}$ & $1.3 \times 10^{5}$ \\
\hline \multirow[t]{2}{*}{6.} & \multirow[t]{2}{*}{ Laceration myiasis } & Cattle & 5 & 18 & 9 & $4.7 \times 10^{5}$ & $1.3 \times 10^{5}$ \\
\hline & & Turkey & 1 & 18 & 9 & $4.1 \times 10^{5}$ & $1.0 \times 10^{5}$ \\
\hline
\end{tabular}

Table.2 Pattern of wound healing during the study period

\begin{tabular}{|c|c|c|c|c|c|c|c|c|c|}
\hline \multirow[t]{2}{*}{$\begin{array}{l}\text { S. } \\
\text { No }\end{array}$} & \multirow[t]{2}{*}{ Type of wound } & \multirow[t]{2}{*}{$\begin{array}{l}\text { Species } \\
\text { affected }\end{array}$} & \multirow[t]{2}{*}{$\begin{array}{l}\text { Details } \\
\text { of cases }\end{array}$} & \multicolumn{6}{|c|}{$\begin{array}{c}\text { Diameter of wounds }(\mathrm{mm}) \text { during the periods } \\
\text { of treatment }\end{array}$} \\
\hline & & & & $\begin{array}{l}0^{\text {th }} \\
\text { Day }\end{array}$ & $\begin{array}{l}3^{\text {rd }} \\
\text { Day }\end{array}$ & $\begin{array}{c}6^{\text {th }} \\
\text { Day }\end{array}$ & $\begin{array}{c}9^{\text {th }} \\
\text { Day }\end{array}$ & $\begin{array}{l}12^{\text {th }} \\
\text { Day }\end{array}$ & $\begin{array}{l}15^{\text {th }} \\
\text { Day }\end{array}$ \\
\hline \multirow[t]{6}{*}{1.} & \multirow[t]{6}{*}{ FMD myiasis } & \multirow[t]{6}{*}{ Cattle } & 1 & 22 & 17 & 13 & 10 & 6 & 0 \\
\hline & & & 2 & 15 & 13 & 10 & 5 & 2 & 0 \\
\hline & & & 3 & 20 & 16 & 12 & 7 & 4 & 0 \\
\hline & & & 4 & 26 & 21 & 18 & 14 & 4 & 0 \\
\hline & & & 5 & 30 & 22 & 15 & 13 & 7 & 0 \\
\hline & & & 6 & 19 & 14 & 10 & 5 & 2 & 0 \\
\hline \multirow[t]{4}{*}{2.} & \multirow[t]{4}{*}{ Surgical wound } & \multirow[t]{4}{*}{ Cattle } & 1 & 28 & 13 & 5 & 0 & 0 & 0 \\
\hline & & & 2 & 24 & 11 & 3 & 0 & 0 & 0 \\
\hline & & & 3 & 18 & 10 & 2 & 0 & 0 & 0 \\
\hline & & & 4 & 18 & 12 & 2 & 0 & 0 & 0 \\
\hline \multirow[t]{4}{*}{3.} & \multirow[t]{4}{*}{ Foot rot } & \multirow[t]{4}{*}{ Cattle } & 1 & 22 & 18 & 10 & 2 & 0 & 0 \\
\hline & & & 2 & 24 & 19 & 12 & 5 & 0 & 0 \\
\hline & & & 3 & 25 & 19 & 13 & 4 & 0 & 0 \\
\hline & & & 4 & 20 & 16 & 12 & 8 & 0 & 0 \\
\hline \multirow[t]{4}{*}{4.} & \multirow[t]{4}{*}{ Ruptured pox leisons } & \multirow[t]{4}{*}{ Cattle } & 1 & 12 & 7 & 5 & 3 & 0 & 0 \\
\hline & & & 2 & 19 & 14 & 11 & 7 & 0 & 0 \\
\hline & & & 3 & 16 & 12 & 9 & 4 & 0 & 0 \\
\hline & & & 4 & 15 & 8 & 6 & 4 & 0 & 0 \\
\hline 5. & $\begin{array}{l}\text { Unhealed mouth of a } \\
\text { completely evacuated and } \\
\text { drained udder abscess }\end{array}$ & Cattle & 1 & 52 & 47 & 36 & 22 & 10 & 0 \\
\hline \multirow[t]{6}{*}{6.} & \multirow[t]{6}{*}{ Laceration myiasis } & \multirow[t]{5}{*}{ Cattle } & 1 & 30 & 24 & 18 & 9 & 0 & 0 \\
\hline & & & 2 & 32 & 25 & 17 & 10 & 0 & 0 \\
\hline & & & 3 & 28 & 22 & 14 & 8 & 0 & 0 \\
\hline & & & 4 & 25 & 18 & 13 & 7 & 0 & 0 \\
\hline & & & 5 & 26 & 22 & 17 & 10 & 0 & 0 \\
\hline & & Turkey & 1 & 25 & 18 & 13 & 7 & 0 & 0 \\
\hline
\end{tabular}




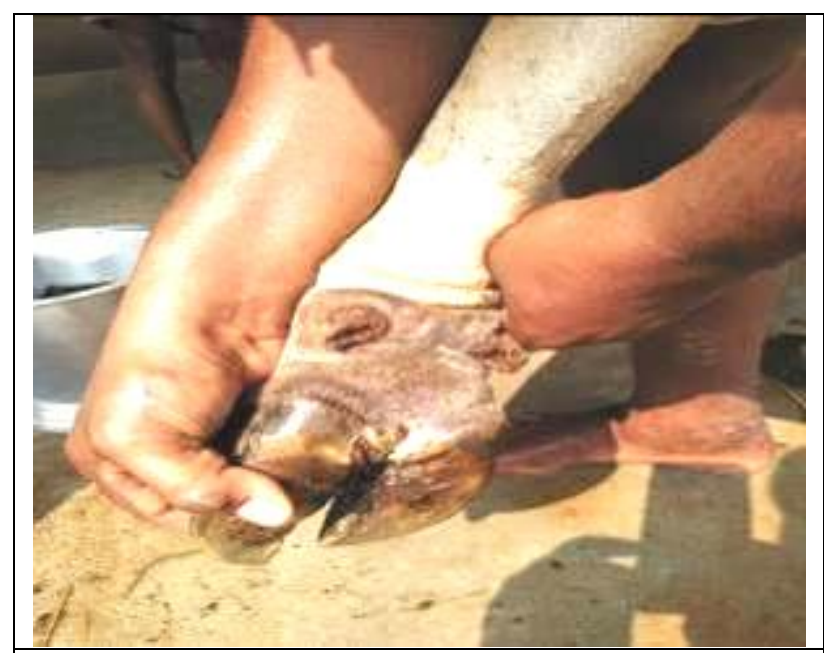

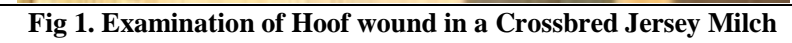
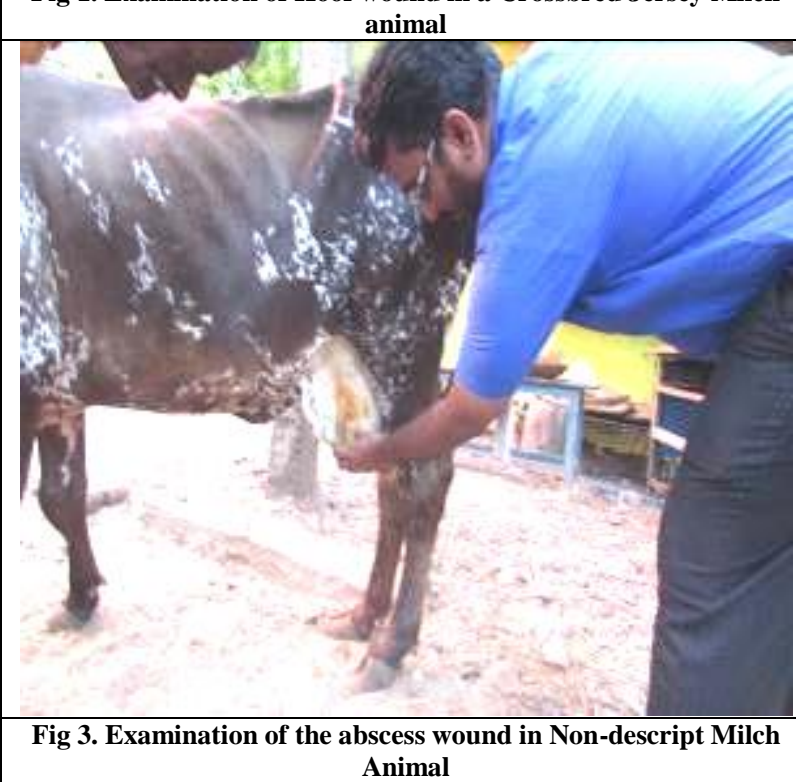

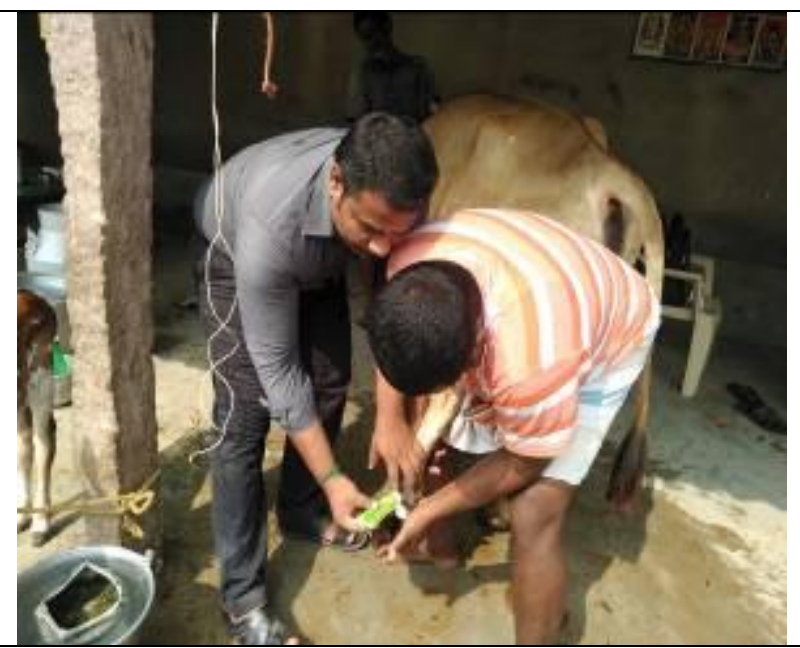

Fig 2. Application of TANUVAS Nano Heal Gel in Crossbred Jersey animal

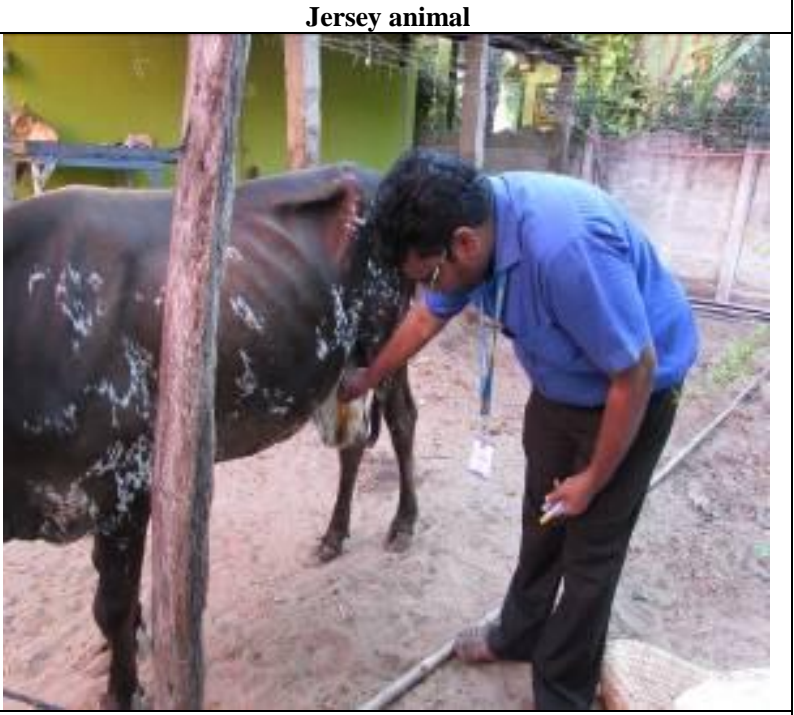

Fig 4. Collecting impression of pus in the wound for assessing

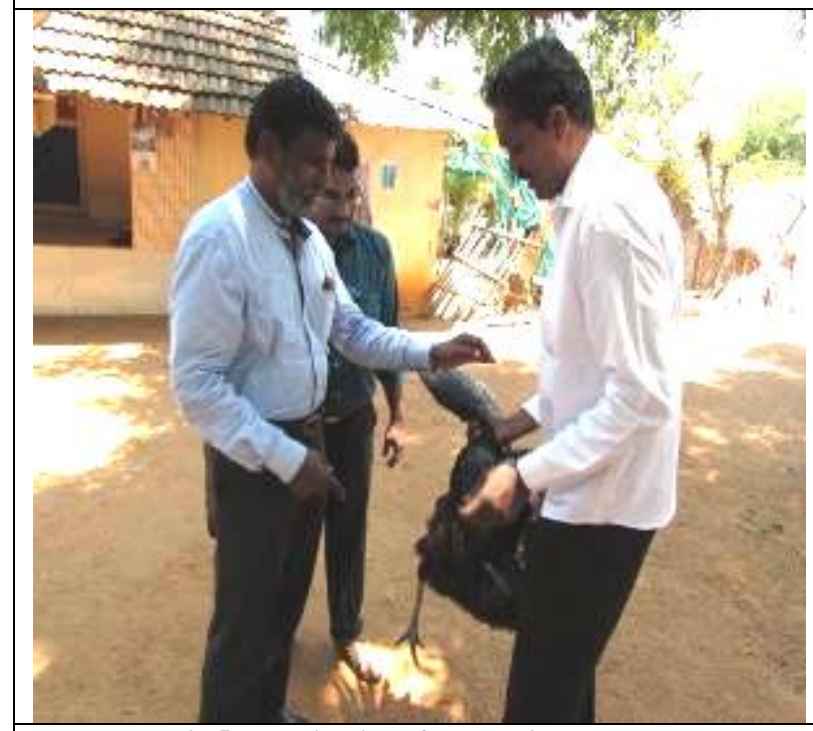

Fig 5. Examination of Wound in a Turkey the bacterial load

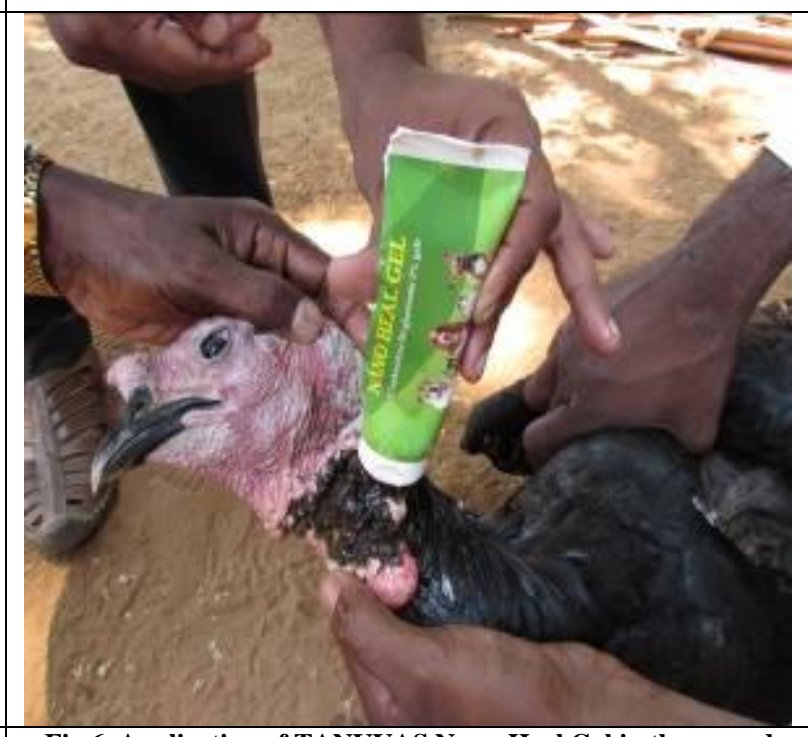

Fig 6. Application of TANUVAS Nano-Heal Gel in the wound 
The unhealed mouth of the improperly united lips of a drained, treated udder abscess could be successfully treated by TANUVAS Nano heal gel, although it took about 12 days. Ruptured Pox lesions in teats of four milch animals could be treated successfully with 18 applications. The maggot infested lacerated wound recorded both in cattle and turkey (Fig 5 and 6) showed complete healing in 9 days. No allergic reactions or other complications could be observed during/ after the study. The wound healing activity was deemed either good or acceptable in the cases, whatever may the nature and type of wound. But the time taken for healing varied based on the type of wound conditions. No wound was categorized negatively in terms of healing. The clinical indications of the topical gel containing gelatin and chitosan as the natural polymers followed by addition of $2 \%$ chlorhexidine and $5 \%$ calcium phosphate nanoparticles showed strong anti-microbial activity against wound causing bacteria (Viswanathan et al., 2016).

The present study proved that, the TANUVAS Nano- Heal Gel was very effective in terms of reducing the bacterial load and improving the wound healing process.

In conclusion the efficacy of the Nano-heal gel depends on the nature and type of wound. The gel was found to be effective in reducing the microbial load in the wound sites and exhibited strong antibacterial activity.

\section{References}

Azad, A.K., N. Sermsintham, S. Chandrkrachang and Stevens, W.F. 2004. Chitosan membrane as a woundhealing dressing; characterization and clinical application. J Biomed Mater Res B Appl Biomater. 69B(2): 216222.

Bennet, R. 1988. Fundamentals of cutaneous surgery. St. Louis: C.V.Mosby. Pp:778. Boateng, J.S., K.H. Matthews, H.N. Stevens and Eccleston, G.M. 2008. Wound healing dressing and drug delivery systems: a review. J Pharm Sci. 97(8): 2892-2923.

Bose, S., and Tarafder, S. 2012. Calcium phosphate ceramic systems in growth factor and drug delivery for bone tissue engineering: a review. Acta Biomater. 8: 1401-1421.

Chan, E.W.C., Y.Y. Lim, L.F. Wong, F.S. Lianto, S.K. Wong, K.K. Lim, C.E. Joe and Lim, T.Y. 2008. Antioxidant and tyrosinase inhibition properties of leaves and rhizomes of ginger species. Food Chem. 109(3): 477-483.

Chen, T., H.D. Embree, E.M. Brown, M.M. Taylor and Payne, G.F. 2003. Enzymecatalyzed gel formation of gelatin and chitosan: potential for in situ applications. Biomaterials. 24: 28312841.

Mogosanu, G.D., and Grumezescu, A.M. 2014. Natural and synthetic polymers for wounds and burns dressing. Int $\mathbf{J}$ Pharm. 463(2): 127-136.

Mullany, L.C., G.L. Darmstadt and Tielsch, J.M. 2006. Safety and impact of chlorhexidine antisepsis interventions for improving neonatal health in developing countries. Padiatr Infect Dis J. 25(8): 665-675.

Nayak, B.S., R.M. Julien and Godwin, I. 2010. Wound healing potential of ethanolic extract of Kalanchoe pinnata Lam. Leaf- A preliminary study. Ind $\mathbf{J}$ Exp Biol. 48(6): 572-576.

Ong, S.Y., J. Wu, S.M. Moochhala, M.H. Tan and Lu, J. 2008. Development of a chitosan-based wound dressing with improved hemostatic and antimicrobial properties. Biomaterials. 29: 43234332.

Rajinder, R., P. Shahid, P.K. Verma and Pankaj, N.K. 2008. Medicinal Plants 
and their Role in wound healing. Vetscan. 3(1): 1-7.

Tanaka, A., T. Nagate and Matsuda, H. 2005. Acceleration of wound healing by gelatin film dressings with epidermal growth factor. J Vet Med Sci. 67(9): 909-913.

Viswanathan, K., P. Monisha, M. Srinivasan,
D. Swathi, M. Raman and Dhinakar Raj, G. 2016. Chlorhexidine-calcium phosphate nanoparticles - Polymer mixer based wound healing cream and their applications. Mater Sci Eng C Mater Biol Appl. 67: 516-521.

\section{How to cite this article:}

Rajesh, N. V., S. Ilavarasan and Vijayalingam, T. A. 2020. Study on the Wound Healing Activity of TANUVAS Nano-Heal Topical Gel in Clinical Cases of Cattle and Turkey. Int.J.Curr.Microbiol.App.Sci. 9(07): 2147-2153. doi: https://doi.org/10.20546/ijcmas.2020.907.250 